\title{
HUBUNGAN INDEKS MASSA TUBUH, LINGKAR PINGGANG DAN RASIO LINGKAR PINGGANG TINGGI BADAN DENGAN KADAR GULA DARAH PENGEMUDI BUS ANTAR KOTA
}

\author{
Alexander Halim Santoso' ${ }^{1}$, Idawati Karjadidjaja², Frisca ${ }^{3}$, Susy Olivia Lontoh ${ }^{4}$ \\ ${ }^{1}$ Bagian Ilmu Gizi, Fakultas Kedokteran, Universitas Tarumanagara \\ Email: alexanders@fk.untar.ac.id \\ ${ }^{2}$ Bagian Ilmu Gizi, Fakultas Kedokteran, Universitas Tarumanagara \\ Email: idawatik@fk.untar.ac.id \\ ${ }^{1}$ Bagian Ilmu Gizi, Fakultas Kedokteran, Universitas Tarumanagara \\ Email: frisca@fk.untar.ac.id \\ ${ }^{4}$ Bagian Fisiologi, Fakultas Kedokteran, Universitas Tarumanagara \\ Email: susyo@fk.untar.ac.id
}

Masuk: 15-05-2020, revisi: 06-08-2020, diterima untuk diterbitkan: 04-10-2020

\begin{abstract}
ABSTRAK
Diabetes mellitus (DM) merupakan suatu penyakit metabolik yang ditandai oleh peningkatan kadar gula darah (hiperglikemia) akibat produksi insulin yang tidak mencukupi atau keadaan dimana tubuh tidak dapat menggunakan insulin dengan efektif. Kondisi hiperglikemia kronik berhubungan dengan kerusakan, disfungsi, dan kegagalan dari organ-organ seperti mata, ginjal, saraf, jantung dan pembuluh darah. Diabetes melitus dan komplikasinya dapat mempengaruhi kemampuan mengemudi. Prevalensi hiperglikemia di kalangan pengendara bus sebesar 52,1\%. Indeks Massa Tubuh (IMT), lingkar pinggang (LP) dan Rasio lingkar pinggang terhadap tinggi badan sering dihubungkan dengan kejadian Diabetes tipe 2, namun hasilnya masih banyak dipengaruhi oleh banyak faktor seperti etnis dan jenis kelamin. Penelitian ini bertujuan untuk melihat bagaimana hubungan IMT, lingkar pinggang dan rasio lingkar pinggang terhadap tinggi badan dengan diabetes melitus pada pengemudi bus antar kota. Penelitian ini merupakan penelitian analitik dengan desain potong lintang yang melibatkan 176 subjek. Didapatkan 54\% subjek dengan status gizi obese, 53,4\% subjek dengan lingkar pinggang di atas $90 \mathrm{~cm}, 71,6 \%$ subjek dengan rasio lingkar pinggang terhadap tinggi badan di atas 0,5. Didapatkan hubungan yang bermakna secara statistik antara indeks massa tubuh dengan kadar gula darah puasa $(p=0,035)$, antara lingkar pinggang dengan kadar gula darah puasa $(p=0,009)$. Tidak didapatkan hubungan bermakna secara statistik antara rasio lingkar pinggang terhadap tinggi badan dengan kadar gula darah puasa $(p=0,274)$. Sebagai kesimpulan, IMT dan Lingkar pinggang dapat digunakan sebagai parameter terhadap risiko timbulnya diabetes pada pengemudi.

Kata kunci: diabetes melitus; indeks massa tubuh; lingkar pinggang; rasio lingkar pinggang terhadap tinggi badan; pengemudi bus

ABSTRACT

Diabetes mellitus (DM) is a metabolic disease characterized by elevated blood sugar levels (hyperglycaemia) due to insufficient production of insulin or the condition where the body cannot use insulin effectively. The condition of chronic hyperglycaemia relates to the damage, dysfunction and failure of organs such as the eyes, kidneys, nerves, heart and blood vessels. Diabetes Mellitus and its complications can affect the ability to drive. The prevalence of hyperglycaemia among bus drivers is 52,1\%. Body mass Index (BMI), waist circumference (WC) and the ratio of waist circumference to height are often associated with the occurrence of type 2 Diabetes, but the results are still heavily influenced by many factors such as ethnicity and gender. This research aims to observe the association of BMI, waist circumference and waist circumference to height ratio to diabetes mellitus among inter-city bus drivers. This is an analytical research with cross-sectional design involving 176 subjects. Fifty four percent subjects were obese, $53.4 \%$ of subjects have a waist circumference above $90 \mathrm{~cm}, 71.6 \%$ of subjects with a waist-to-height ratio of over 0.5. The association between BMI and fasting blood sugar was significant $(p=0,035)$, and also between the waist circumference and fasting blood sugar $(p=0,009)$. There is no statistically significant association between the ratio of waist circumference to height and fasting blood sugar level $(P=0,274)$. As Conclusion, The BMI and waist circumference can be used as indicators to the risk of diabetes among bus drivers.
\end{abstract}

Keywords diabetes mellitus, body mass index, waist circumference, waist circumference to height ration, bus driver 


\section{PENDAHULUAN}

Diabetes mellitus (DM) merupakan suatu penyakit metabolik yang ditandai oleh peningkatan kadar gula darah (hiperglikemia) akibat produksi insulin yang tidak mencukupi atau keadaan dimana tubuh tidak dapat menggunakan insulin dengan efektif.(Siddiqui et al., 2013) Kondisi hiperglikemia kronik berhubungan dengan kerusakan, disfungsi, dan kegagalan dari organ-organ seperti mata, ginjal, saraf, jantung dan pembuluh darah.(Siddiqui et al., 2013; World Health Organization, 2016) Prevalensi DM pada orang dewasa berusia $>18$ tahun meningkat dari 4,7\% menjadi 8,5\% pada tahun 2014 dan meningkat dengan cepat di negara-negara berpenghasilan rendah hingga menengah.(World Health Organization, 2016) Pengemudi (supir) merupakan kelompok pekerja yang kondisi kesehatannya berhubungan langsung dengan keselamatan penumpang. Diabetes melitus dan komplikasinya dapat mempengaruhi kemampuan mengemudi. Izadi (2013) menemukan bahwa prevalensi hiperglikemia di kalangan pengemudi sebesar 52,1\% sementara Saberi (2011) mendapatkan prevalensi diabetes sebesar 7\%.(Izadi, Malek, Aminian, \& Saraei, 2013; Saberi, Moravveji, Fakharian, Kashani, \& Dehdashti, 2011).

Indeks massa tubuh (IMT) merupakan pengukuran antropometri yang paling sering digunakan untuk mengklasifikasikan status gizi pada orang dewasa, tapi tidak dapat membedakan peningkatan berat badan yang disebabkan oleh peningkatan massa otot atau massa lemak. Pemeriksaan lingkar pinggang, rasio lingkar pinggang terhadap tinggi badan merupakan pemeriksaan yang dapat digunakan untuk memperkirakan distribusi lemak tubuh, dan berhubungan erat dengan faktor-faktor risiko penyakit kardiovaskular.(D. Kim, Kim, \& Jeong, 2017; Lam, Koh, Chen, Wong, \& Fallows, 2015) Indeks Massa Tubuh (IMT), lingkar pinggang (LP) dan Rasio lingkar pinggang terhadap tinggi badan sering dihubungkan dengan kejadian Diabetes tipe 2, namun hasilnya masih banyak dipengaruhi oleh banyak faktor seperti etnis dan jenis kelamin.(Vazquez, Duval, Jacobs, \& Silventoinen, n.d.) Penelitian ini bertujuan untuk melihat bagaimana hubungan pemeriksaan IMT, lingkar pinggang dan rasio lingkar pinggang terhadap tinggi badan dengan kadar gula darah pada pengemudi bus antar kota.

\section{METODE}

Penelitian ini merupakan penelitian analitik dengan desain potong lintang (cross sectional) dan sudah mendapatkan ijin penelitian dari komisi etik Universitas Tarumanagara (UTHREC) Nomor Proyek PPZ20182014.

\section{Subjek}

Subjek penelitian merupakan pengemudi bus antar kota di perusahaan GM berusia 20-60 tahun yang dipilih dengan menggunakan consecutive sampling. Berdasarkan rumus perhitungan perbedaan dua proporsi independen, dengan alfa 0,05 dan power $80 \%$, didapatkan jumlah sampel minimal sebesar 176 subjek. Subjek selanjutnya diberikan penjelasan terkait penelitian dan subjek yang bersedia mengikuti penelitian diminta untuk menanda-tangani lembar persetujuan penelitian (inform consent). Subjek yang menjalani pengobatan anti diabetes secara oral maupun injeksi, dan mengalami kelainan bentuk tubuh tidak dapat mengikuti penelitian ini.

\section{Kuesioner}

Subjek dibagikan kuesioner dan dilakukan wawancara oleh peneliti guna mendapatkan data-data dasar mencakup usia, agama, pendidikan, lama tidur, kebiasaan merokok, kebiasaan minum kopi dan teh dan kebiasaan olahraga.

\section{Pengukuran Antropometri}

Pengukuran antropometri mencakup pengukuran berat badan (BB), tinggi badan (TB), lingkar pinggang (LP) dan rasio lingkar pinggang terhadap tinggi badan. Pengukuran berat badan menggunakan timbangan merek SECA 750 dan pengukuran tinggi badan menggunakan microtoise (Johnson and Johnson Co. Ltd). Pengukuran berat badan dilakukan dengan cara 
menginstruksikan kepada subjek untuk melepaskan alas kaki dan asesoris yang melekat pada tubuh seperti ban pinggang, dompet, jam tangan. Subjek kemudian diminta untuk naik ke atas timbangan dan memandang lurus ke depan, dan kedua lengan tergantung lepas di samping badan. Pengukuran tinggi badan dilakukan dengan meminta subjek melepaskan alas kaki, dan berdiri menempel pada dinding. Pengukur memastikan bagian belakang kepala, bahu, bokong, betis dan tumit menempel pada dinding. Subjek diminta berdiri tegak, kedua kaki dirapatkan dan pandangan subjek lurus ke dapan. Pengukuran lingkar pinggang dilakukan dengan menggunakan pita pengukur SECA 201 pada titik tengah antara batas bawah tulang rusuk terakhir dan batas atas lengkung tulang panggul (crista iliaca). Indeks massa tubuh (IMT), rasio lingkar pinggang terhadap tinggi badan didapatkan melalui perhitungan BB, TB dan LP. Masing-masing pengukuran dilakukan sebanyak dua kali dan dicatat nilai rata-ratanya. Perbedaan hasil pengukuran yang diperbolehkan adalah $0,1 \mathrm{~cm}$.

\section{Pengukuran gula darah puasa}

Sebelum pengambilan darah, subjek diminta untuk berpuasa selama 8 jam. Darah diambil dari salah satu pembuluh darah balik (vena) di lipat siku. Sebelum pengambilan, dilakukan tindakan antiseptik dengan menggunakan cairan alkohol $70 \%$ pada permukaan kulit yang kemudian dibiarkan mengering terlebih dahulu. Lengan atas diikat dengan perban elastis, dan tenaga medis mengidentifikasi pembuluh darah vena yang akan ditusuk dengan jarum suntik. Saat penusukan akan terasa nyeri sedikit, darah kemudian diambil sebanyak yang diperlukan. Setelah jumlah darah terpenuhi, jarum dilepaskan dan tempat penusukan dibersihkan dengan kapas alkohol dan ditutup dengan menggunakan kapas dan perekat. Tabung berisi darah dimasukkan ke dalam wadah dan dibawa ke laboratorium untuk pemeriksaan.

\section{Analisis Statistik}

Analisis statistik menggunakan aplikasi lunak Statistical Package for Social Sciences (SPSS) versi 20 dari IBM. Data univariat (karakteristik) disajikan dalam bentuk tabel dengan nilai persentase (\%), mean dan simpangan baku. Data bivariat untuk melihat hubungan antar variabel disajikan dalam bentuk tabel $2 \times 2$ dan dianalisis menggunakan uji Chi-square dengan nilai signifikansi $<0,05$.

\section{HASIL DAN PEMBAHASAN \\ Hasil}

Karakteristik subjek pada penelitian ini, didapatkan 176 subjek, seluruhnya berjenis kelamin laki-laki. Sebanyak 77,8\% subjek berusia antara 30-50 tahun dan sebanyak 14,2\% berusia di atas 50 tahun. Lebih dari limapuluh persen subjek $(97,8 \%)$ dengan riwayat pendidikan tamat pendidikan dasar (SD). Lebih dari delapan puluh persen subjek (83\%) memiliki riwayat lama tidur kurang dari 7 jam per hari, dan 89,2\% memiliki kebiasaan merokok. Didapatkan hampir sembilan puluh persen subjek $(89,8 \%)$ sudah merokok lebih dari 10 tahun, dengan rata-rata jumlah rokok yang dihirup per harinya $<12$ batang $(68,2 \%)$. Dari 176 subjek yang diteliti, sebanyak 144 subjek (81,8\%) memiliki kebiasaan minum kopi dan 150 subjek $(85,22 \%)$ memiliki kebiasaan minum teh. Dari subjek yang memiliki kebiasaan minum kopi, empat puluh dua persen $(42,68 \%)$ subjek minum kopi dengan gula, dan dua puluh dua persen $(22,37 \%)$ minum kopi instan. Lebih dari delapan puluh persen $(87,5 \%)$ mengonsumsi kopi kurang dari 3 cangkir per hari. Sebanyak lima puluh enam persen $(56,13 \%)$ subjek mengonsumsi teh manis dan lebih dari delapan puluh persen $(83,19 \%)$ mengonsumsi teh kurang dari 3 gelas per harinya. Sebanyak dua puluh enam $(26,1 \%)$ subjek memiliki kebiasaan mengonsumsi minuman berenergi, namun lebih dari tujuh persen $(72,84 \%)$ tidak mengetahui nama minuman berenergi yang dikonsumsi. Lebih dari lima puluh persen $(54,5 \%)$ tidak memiliki kebiasaan berolahraga. Dari delapan puluh subjek $(45,5 \%)$ yang memiliki kebiasaan berolahraga, lebih dari tujuh puluh persen $(74,4 \%)$ berolah-raga kurang dari 30 menit per kali. 
Tabel 1. Karakteristik Subjek $(\mathrm{N}=176)$

\begin{tabular}{|c|c|c|c|}
\hline & Mean \pm SD & $\mathbf{n}$ & $\%$ \\
\hline Usia (tahun) & $41,71 \pm 8,1$ & & \\
\hline$\leq 20$ & & 0 & 0,0 \\
\hline $21-30$ & & 14 & 8,0 \\
\hline $31-40$ & & 68 & 38,6 \\
\hline $41-50$ & & 69 & 39,2 \\
\hline $51-60$ & & 23 & 13,1 \\
\hline$>60$ & & 2 & 1,1 \\
\hline \multicolumn{4}{|l|}{ Pendidikan } \\
\hline Tidak sekolah & & 4 & 2,3 \\
\hline SD/Tamat SD & & 39 & 22,2 \\
\hline SMP/Tamat SMP & & 75 & 42,6 \\
\hline SMA/Tamat SMA & & 58 & 33,0 \\
\hline Lama Tidur (jam/hari) & $5,7 \pm 1,8$ & & \\
\hline$<7$ & & 146 & 83,0 \\
\hline$\geq 7$ & & 30 & 17,0 \\
\hline \multicolumn{4}{|l|}{ Merokok } \\
\hline $\mathrm{Ya}$ & & 157 & 89,2 \\
\hline Tidak & & 19 & 10,8 \\
\hline Lama merokok (Tahun) & $20,7 \pm 8,64$ & & \\
\hline$<10$ & & 18 & 10,2 \\
\hline$\geq 10$ & & 158 & 89,8 \\
\hline Jumlah rokok (batang/hari) & $11,86 \pm 9,7$ & & \\
\hline$\leq 12$ & & 120 & 68,2 \\
\hline$>12$ & & 56 & 31,8 \\
\hline \multicolumn{4}{|l|}{ Minum Kopi } \\
\hline $\mathrm{Ya}$ & & 144 & 81,8 \\
\hline Tidak & & 32 & 18,2 \\
\hline \multicolumn{4}{|l|}{ Jenis Kopi yang Diminum } \\
\hline Hitam pahit & & 17 & 11,88 \\
\hline Hitam + gula & & 61 & 42,65 \\
\hline Kopi instan & & 32 & 22,37 \\
\hline Kopi tubruk & & 1 & 0,69 \\
\hline Kopi susu & & 15 & 10,48 \\
\hline Lebih dari 1 jenis & & 16 & 11,18 \\
\hline Lainnya & & 1 & 0,69 \\
\hline \multicolumn{4}{|c|}{ Jumlah kopi yang diminum (per cangkir) } \\
\hline$<3$ cangkir & & 154 & 87,5 \\
\hline$\geq 3$ cangkir & & 22 & 12,5 \\
\hline Minum Teh & & $\mathrm{n}$ & $\%$ \\
\hline Ya & & 150 & 85,22 \\
\hline Tidak & & 26 & 14,78 \\
\hline \multicolumn{4}{|l|}{ Jenis Teh yang Diminum } \\
\hline Teh Tawar & & 59 & 38,06 \\
\hline Teh Manis & & 87 & 56,13 \\
\hline Keduanya & & 9 & 5,81 \\
\hline \multicolumn{4}{|l|}{ Jumlah Teh yang diminum per hari } \\
\hline$<3$ gelas & & 99 & 83,19 \\
\hline$\geq 3$ gelas & & 20 & 16,81 \\
\hline \multicolumn{4}{|l|}{ Mengomsumsi Minuman Berenergi } \\
\hline $\mathrm{Ya}$ & & 46 & 26,1 \\
\hline Tidak & & 130 & 73,9 \\
\hline \multicolumn{4}{|l|}{ Riwayat Berolahraga } \\
\hline $\mathrm{Ya}$ & & 80 & 45,4 \\
\hline Tidak & & 96 & 54,6 \\
\hline Lama Berolahraga (menit/kali) & $31,2 \pm 48,9$ & & \\
\hline$<30 \mathrm{menit} / \mathrm{kali}$ & & 131 & 74,4 \\
\hline$\geq 30 \mathrm{menit} / \mathrm{kali}$ & & 45 & 25,6 \\
\hline
\end{tabular}




\section{Indeks Massa Tubuh (IMT)}

Berdasarkan klasifikasi IMT dari WHO untuk Asia Pasifik, didapatkan rata-rata IMT subjek adalah $25,85 \mathrm{~kg} / \mathrm{m}^{2}$, dimana 95 subjek (54\%) dengan status gizi obese (Tabel 2).

\section{Lingkar Pinggang}

Berdasarkan pengukuran lingkar pinggang, didapatkan rata-rata lingkar pinggang subjek adalah $90,56 \mathrm{~cm}$, dimana lebih dari lima puluh persen $(53,4 \%)$ memiliki lingkar pinggang diatas nilai normal (Tabel 2)

\section{Rasio Lingkar Pinggang terhadap tinggi badan}

Pada penelitian ini didapatkan rata-rata rasio lingkar pinggang terhadap tinggi badan subjek adalah 0,54 dimana, sebanyak 126 subjek $(71,6 \%)$ memiliki rasio di atas 0,5. (Tabel 2)

\section{Sebaran Kadar Gula Darah Puasa}

Dari hasil pengukuran gula darah puasa, didapatkan kadar gula darah puasa subjek adalah 101,11 $\mathrm{mg} / \mathrm{dL}$ dimana $88,6 \%$ subjek memiliki kadar gula darah normal (Tabel 2)

Tabel 2. Sebaran Status Gizi, Lingkar Pinggang, Rasio Lingkar Pinggang terhadap Tinggi Badan, dan Kadar Gula Darah Puasa

\begin{tabular}{|c|c|c|c|}
\hline & Jumlah & Mean \pm SD & Persentase $(\%)$ \\
\hline $\begin{array}{l}\text { Status Gizi berdasarkan Indeks } \\
\text { Massa Tubuh (IMT) }\left(\mathrm{kg} / \mathrm{m}^{2}\right)\end{array}$ & & $25,85 \pm 5,93$ & \\
\hline Kurang $(\leq 18,5)$ & 11 & & 6,2 \\
\hline Normal $(18,5-22,9)$ & 70 & & 39,8 \\
\hline Overweight $(23,0-24,9)$ & 0 & & 0 \\
\hline Obese-1 $(25,0-29,9)$ & 64 & & 36,4 \\
\hline Obese-2 ( $\geq 30)$ & 31 & & 17,6 \\
\hline Lingkar Pinggang (cm) & & $90,56 \pm 13,85$ & \\
\hline $\operatorname{Normal}(\leq 90 \mathrm{~cm})$ & 82 & & 46,6 \\
\hline Tidak Normal/Obese $(>90 \mathrm{~cm}$ ) & 94 & & 53,4 \\
\hline $\begin{array}{l}\text { Rasio Lingkar Pinggang } \\
\text { Terhadap Tinggi Badan }\end{array}$ & & $0,54 \pm 0,08$ & \\
\hline$\leq 0,5$ & 50 & & 28,4 \\
\hline$>0,5$ & 126 & & 71,6 \\
\hline $\begin{array}{l}\text { Kadar Gula Darah } \\
(\mathrm{mg} / \mathrm{dL})\end{array}$ & & $101,11 \pm 41,003$ & \\
\hline Normal $(<126)$ & 156 & & 88,6 \\
\hline Tinggi $(\geq 126)$ & 20 & & 11,4 \\
\hline
\end{tabular}




\section{Hubungan Indeks Massa Tubuh (IMT) dengan Gula Darah Puasa}

Dari hasil analisis statistik, didapatkan hubungan yang bermakna antara Indeks Massa Tubuh (IMT) dengan kadar gula darah puasa subjek $(p<0,05)$ (Tabel 3)

\section{Hubungan Lingkar Pinggang (LP) dengan Gula Darah Puasa}

Dari hasil analisis statistik, didapatkan hubungan yang bermakna antara lingkar pinggang dengan kadar gula darah puasa subjek $(p<0,05)$ (Tabel 3)

\section{Hubungan Rasio Lingkar Badan Tinggi Badan (RLPtTB) dengan Gula Darah Puasa}

Dari hasil analisis statistik, tidak didapatkan hubungan yang bermakna antara rasio lingkar pinggang terhadap tinggi badan dengan kadar gula darah puasa subjek $(p>0,05)$ (Tabel 3$)$

Tabel 3. Hubungan Indeks Massa Tubuh (IMT), Lingkar Pinggang, dan Rasio Lingkar Badan terhadap Tinggi Badan (RLPtTB) dengan Gula Darah Puasa

\begin{tabular}{llccccc}
\hline & & \multicolumn{5}{c}{ Gula Darah Puasa (mg/dL) } \\
& & \multicolumn{1}{c}{$\geq$} & \multicolumn{2}{c}{$<126$} & $p$ \\
\hline IMT & Overweight/Obese & 18 & $(90,0 \%)$ & 107 & $(68,6 \%)$ & 0,035 \\
& Normal & 2 & $(10,0 \%)$ & 49 & $(31,4 \%)$ & \\
& & & & & & \\
LP & $>90 \mathrm{~cm}$ & 16 & $(80 \%)$ & 78 & $(50 \%)$ & 0,009 \\
& $\leq 90 \mathrm{~cm}$ & 4 & $(20 \%)$ & 78 & $(50 \%)$ & \\
\multirow{2}{*}{ RLPtTB } & $>0,5$ & 16 & $(80 \%)$ & 110 & $(70,5 \%)$ & 0,274 \\
& $\leq 0,5$ & 4 & $(20 \%)$ & 46 & $(29,5 \%)$ & \\
& & 4 & & &
\end{tabular}

\section{Pembahasan}

Pada penelitian ini ditemukan bahwa sebanyak 77,8\% subjek berusia antara 31-50 tahun dan $1,1 \%$ berusia diatas 60 tahun. Hasil ini sesuai dengan hasil yang didapatkan oleh Laksman (2014), Mohebi (2009) dan Saberi (2011).(Lakshman, Manikath, Rahim, \& Anilakumari, 2014; Mohebbi et al., 2010; Saberi et al., 2011) Prevalensi diabetes melitus tipe 2 meningkat sejalan dengan bertambahnya usia. Obesitas sentral dan resistensi insulin merupakan kondisi yang sering ditemukan pada penderita diabetes berusia lanjut. Menurunnya massa bebas lemak dan meningkatnya massa lemak, terutama lemak sentral, merupakan salah satu penyebab terjadinya resistensi insulin. Sejalan dengan pertambahan usia, kapasitas sel beta pankreas juga berkurang.(Suastika, Dwipayana, Semadi, \& Kuswardhani, 2018)

Sebanyak 172 subjek pada penelitian ini sudah menyelesaikan pendidikan dasar (tamat SD) (97,7\%). Hasil yang sama juga didapatkan oleh Laksman, dimana 99,5\% pengemudi bus sudah menyelesaikan pendidikan dasar.(Lakshman et al., 2014) Salah satu faktor yang berperan terhadap insiden diabetes melitus adalah tingkat pendidikan. Tingkat pendidikan yang rendah berhubungan dengan insiden diabetes melitus tipe 2.(Agardh et al., 2011; Sacerdote et al., 2012) Tingkat pendidikan yang rendah dapat mempengaruhi faktor resiko lain seperti merokok, aktivitas fisik dan indeks massa tubuh.(Sacerdote et al., 2012)

Pada penelitian ini didapatkan 146 subjek memiliki riwayat tidur kurang dari 7 jam dalam sehari (83,0\%). Laksman juga menemukan bahwa 53,1\% pengemudi bus memiliki riwayat kurag tidur.(Lakshman et al., 2014) Padua-Mansur (2015) menemukan bahwa ada hubungan antara kurangnya jam tidur dengan kegemukan (obesitas), dimana jam tidur yang kurang berhubungan dengan meningkatnya lingkar pinggang.(Mansur et al., 2015; Moreno, Louzada, Teixeira, Borges, \& Lorenzi-Filho, 2006) Obesitas merupakan salah satu faktor sindroma 
metabolik.(Smolensky, Di Milia, Ohayon, \& Philip, 2011) Kurangnya jam tidur juga disebabkan oleh jam kerja yang berlebihan, kualitas tidur yang buruk, penggunaan obat, dan asupan alkohol.(Hirata et al., 2012)

Pada penelitian ini ditemukan $89,2 \%$ subjek merokok. Laksman mendapatkan $46 \%$ pengemudi merokok dan Siu mendapatkan 20,7 pengemudi laki-laki merokok.(Lakshman et al., 2014; Siu et al., 2012) Merokok berhubungan dengan insiden diabetes melitus. Risiko diabetes melitus ditemukan 1,94 kali lebih tinggi pada individu yang merokok $\geq 25$ batang per hari dibandingkan mereka yang tidak merokok.(Rimm, Chan, Stampfer, Colditz, \& Willett, 1995) Data dari "The Cancer Prevention Study” juga menunjukkan bahwa risiko diabetes meningkat pada kelompok yang merokok sebanyak 1 sampai 2 bungkus per hari.(Will, Galuska, Ford, Mokdad, \& Calle, 2001) Risiko Diabetes ditemukan menurun setelah tidak merokok selama 10 tahun. Attvall et al menemukan bahwa merokok dapat menganggu sensitivitas insulin.(Attvall, Fowelin, Lager, Von Schenck, \& Smith, 1993) Akter et al menemukan bahwa resistensi insulin terjadi melalui beberapa mekanisme antara lain stress oksidatif, inflamasi, dan disfungsi endotel.(Akter, Goto, \& Mizoue, 2017) Nikotin di dalam rokok juga berpotensi toksik terhadap fungsi sel betapankreas. Pada kelompok perokok ditemukan sensitivitas insulin 10\%-40\% lebih rendah dibandingkan yang tidak merokok.(Eliasson, Mero, Taskinen, \& Smith, 1997; Facchini, Hollenbeck, Jeppesen, Chen, \& Reaven, 1992)

Pada penelitian ini didapatkan $81,8 \%$ subjek mengonsumsi kopi, 85,22\% subjek mengonsumsi teh, dan $26,1 \%$ mengonsumsi minuman berenergi. Kafein merupakan senyawa di dalam makanan yang dikonsumsi secara luas di dunia. Kafein banyak ditemukan di dalam kopi, teh, soft-drink, coklat. Kadar kafein di dalam kopi dan teh bergantung pula terhadap varietas tumbuhan, cara penanaman, pengolahan dan penyiapannya. Di dalam secangkir kopi (240 ml) terkandung $100 \mathrm{mg}$ kafein, sedangkan dalam secangkir teh berkisar antara 40-120 mg kafein. Kafein berperan sebagai antagonis reseptor adenosin di dalam otak yang menyebabkan efek inhibisi terhadap sistem saraf pusat. Kafein berpotensi untuk menempati reseptor adenosin $\mathrm{A}_{1}$ dan $A_{2 a}$. Reseptor Adenosin $A_{1}$ banyak ditemukan di dalam hipokampus, korteks serebral dan korteks serebelum dan sejumlah nukleus thalamik. Reseptor $\mathrm{A}_{2 \mathrm{a}}$ ditemukan pada area di otak yang kaya akan dopamin. Setelah terjadi penghambatan terhadap adenosin menyebabkan rasa kantuk menghilang.(Heckman, Weil, \& de Mejia, 2010)

Sebuah penelitian klinis yang melibatkan 200,000 laki-laki dan perempuan menunjukkan hubungan terbalik antara konsumsi kafein dengan diabetes melitus. Ulasan penelitian klinis menyatakan bahwa risiko diabetes melitus tipe 2 ditemukan lebih rendah (35\%) pada kelompok yang mengonsumsi kafein (enam cangkir kopi per hari) dan $28 \%$ lebih rendah pada kelompok yang mengonsumsi 4-6 cangkir kopi per hari dibandingkan kelompok yang mengonsumsi kurang dari 2 cangkir per hari.(Dam, Willett, Manson, \& Hu, 2006)

Pada penelitian ini didapatkan $45,5 \%$ subjek melakukan olahraga secara rutin, dengan lama berolahraga <30 menit/kali $(74,4 \%)$. Siu et al mendapatkan 44,2\% pengemudi laki-laki melakukan olahraga dengan rutin.(Siu et al., 2012) Aktivitas fisik adalah semua gerakan yang meningkatkan penggunaan energi, sedangkan exercise adalah aktivitas fisik yang direncanakan dan terstruktur.(Colberg et al., 2016) Exercise dapat memperbaiki kendali glukosa darah pada individu dengan diabetes melitus tipe 2 , mengurangi risiko penyakit kardiovaskular, menurunkan berat badan, dan meningkatkan status kesehatan.(Chen et al., 2015; Lin et al., 2015) Aerobic exercise mencakup gerakan pada otot-otot besar yang dilakukan berulang dan terus menerus, seperti berjalan kaki, bersepeda, jogging, dan berenang. Latihan beban (resistance training) mencakup exercise yang dilakukan tanpa beban, maupun dengan alat dan beban. Disamping itu 
latihan fleksibilitas dan keseimbangan juga bermanfaat, seperti yoga dan tai-chi.(Morriison, Colberg, Mariano, Parson, \& Vinik, 2010)

Latihan aerobik dapat meningkatkan kerja mitokondria, sensitivitas insulin, enzim-enzim oksidatif, compliance pembuluh darah, fungsi paru-paru, fungsi imunitas, dan juga curah jantung. Latihan aerobik dengan intensitas berhubungan dengan penurunan angka mortalitas akibat penyakit kardiovaskular. Pada individu dengan diabetes melitus tipe 2, latihan yang teratur dapat menurunkan nilai $\mathrm{HbA}_{1 \mathrm{C}}$, trigliserida, tekanan darah dan resistensi insulin.(Garber et al., 2011; Sluik et al., 2012; Snowling \& Hopkins, 2006).

\section{Indeks Massa Tubuh}

Pada penelitian ini didapatkan 54\% subjek dengan status gizi Obese, mencakup obesitas derajat $1(36,4 \%)$; obesitas derajat $2(17,6 \%)$. Hasil ini sesuai dengan yang didapatkan oleh Siu et al dimana $52,8 \%$ pengemudi bus berstatus gizi obese derajat 1, dan 9,3\% berstatus obese derajat 2.(Siu et al., 2012) Hasil ini juga sesuai dengan Izadi dimana didapatkan 44,8\% pengemudi berstatus gizi lebih sampai obese derajat 1, dan 20,8\% berstatus gizi obese derajat 2.(Izadi et al., 2013).

Indeks massa tubuh (IMT) merupakan pemeriksaan antropometri yang banyak digunakan untuk menilai status gizi di dalam suatu populasi. Pemeriksaan ini praktis dan hanya membutuhkan peralatan yang sederhana. Komponen pengukuran IMT mencakup tinggi badan dan berat badan. Perubahan nilai IMT dapat memberikan informasi mengenai laju perubahan status gizi, dan dapat digunakan pada kelompok individu berjumlah besar. Kekurangan pengukuran IMT adalah tidak dapat memperkirakan sumber perubahan berat badan, apakah bersumber dari massa otot atau dari massa lemak. Hasil pengukuran IMT seorang individu bisa normal namun masih berisiko terhadap kelebihan lemak. Lemak tubuh dapat dikelompokkan menjadi lemak yang terdapat dibawah kulit (subcutaneous fat) dan lemak viseral. Lemak viseral adalah lemak yang terdapat di abdomen, terutama lemak yang mengelilingi organ-organ internal tubuh. Jumlah lemak viseral yang tinggi menyebabkan seorang individu memiliki risiko yang lebih tinggi terhadap penyakit-penyakit metabolik seperti diabetes melitus, hipertensi dan penyakit kardiovaskular lainnya.(Carrero \& Avesani, 2015; Müller, Braun, Enderle, \& Bosy-Westphal, 2016) Disamping itu pengukuran IMT juga kurang tepat bila dilakukan pada individu dengan massa otot (lean body masss) yang besar (misalnya pada olahragawan, binaragawan). Pengukuran IMT pada kelompok ini dapat menghasilkan nilai IMT yang tinggi sekalipun massa lemak pada kelompok ini kecil. IMT yang tinggi merupakan faktor risiko penting untuk penyakit kardiovaskular, ginjal, diabetes dan juga kanker.

\section{Lingkar Pinggang}

Pada penelitian ini didapatkan 53,4\% subjek memiliki lingkar pinggang di atas $90 \mathrm{~cm}$. Hasil ini sesuai dengan yang didapatkan oleh Siu, dimana ditemukan $46,4 \%$ pengemudi bus di Hongkong memiliki lingkar pinggang di atas $90 \mathrm{~cm}$.(Siu et al., 2012) Lingkar pinggang merupakan alat pengukuran jaringan lemak viseral yang paling praktis. Lemak yang terdapat di dalam abdomen berhubungan dengan status kesehatan.(C. H. Kim, 2016).

Lemak viseral yang berlebih merupakan faktor risiko terhadap diabetes. Bambrick menyatakan bahwa meningkatnya resistensi insulin pada penderita DM berhubungan dengan pelepasan asam lemak bebas. Etnis India, Jepang, Aborigin cenderung untuk menyimpan lemak viseral lebih banyak dibandingkan etnis lainnya.(Bambrick, 2005) Dalam studi-studi epidemiologi, pengukuran lingkar pinggang berhubungan kuat dengan tekanan darah, dislipidemia, kadar gula 
darah puasa, kadar gula darah 2 jam setelah makan. Pada peneltian yang dilakukan oleh National Health and Nutrition Examination Survey (NHNES) ditemukan hubungan lingkar pinggang terhadap faktor-faktor risiko obesitas (kolesterol-LDL, tekanan darah, glukosa darah) yang lebih kuat dibandingkan dengan IMT.(Buchholz \& Bugaresti, 2005)

\section{Rasio Lingkar Pinggang Terhadap Tinggi Badan (RLPtTB)}

Pada Penelitian ini didapatkan sebaran rasio RLPtTB > 0,5 sebanyak 73,6\%. Rasio lingkar pinggang terhadap tinggi badan (RLPtTB) merupakan salah satu pengukuran yang dapat memberikan informasi mengenai distribusi lemak di dalam tubuh. Nilai pengukuran di atas 0,5 menandakan subjek berisiko lebih tinggi terhadap penyakit-penyakit kardiovaskular. Dalam suatu studi yang melibatkan sebelas ribu subjek selama delapan tahun didapatkan bahwa RLPtTB merupakan pengukuran yang lebih baik dibandingkan IMT dalam memperkirakan risiko terhadap serangan jantung, stroke dan mortalitas.(Browning, Hsieh, \& Ashwell, 2010) Pada studi lain yang melibatkan limapuluh ribu subjek selama tigabelas tahun didapatkan RLPtTB merupakan prediktor yang lebih baik untuk kematian akibat penyakit jantung dibandingkan dengan rasio lingkar panggul.(Ashwell, 2011)

Pengukuran RLPtTB lebih baik dibandingkan dengan LP dikarenakan tinggi badan memiliki hubungan yang terbalik dengan morbiditas dan mortalitas penyakit kardiovaskular. Suatu studi di Chili menyatakan bahwa individu berbadan pendek yang disebabkan karena paparan dari lingkungan sejak usia anak anak berisiko lebih tinggi terhadap peningkatan lemak viseral, resistensi insulin dan faktor-faktor kardiometabolik lain di usia dewasa.(Koch et al., 2010).

\section{Hubungan Indeks Massa Tubuh (IMT) dengan Gula Darah Puasa}

Pada penelitian ini didapatkan hubungan yang bermakna secara statistik antara indeks massa tubuh (IMT) dengan gula darah puasa $(p=0,035)$. Hasil ini sesuai dengan Bays (2007) dan Agrawaf (2017).(Agrawal, Kumar Agrawal, Kumari, \& Kumar, 2017; Bays, Chapman, \& Grandy, 2007)

Semakin tinggi nilai IMT, semakin kuat pula hubungan dengan kejadian Diabetes. Pada individu dengan diabetes melitus tipe 2, nilai IMT yang tinggi juga berhubungan rengan risiko komplikasi DM yang semakin besar.(Picone, Gray, Sloan, \& Yashkin, 2015) Namun, hubungan nilai IMT yang tinggi dengan kejadian DM tidak berlaku untuk seluruh etnis di dunia. Bila nilai IMT 30 $\mathrm{kg} / \mathrm{m}^{2}$ diterapkan pada masyarakat di Jepang, hanya $3 \%$ dari populasi masyarakat yang terdiagnosis obesitas. Kondisi tersebut tidak dapat menggambarkan perubahan gaya hidup yang terjadi dalam enam dekade belakangan. Nilai batas IMT pada etnis di Asia sebaiknya diturunkan dari 30 menjadi 25 agar dapat digunakan sebagai prediktor obesitas dan penyakit tidak menular lainnya.

\section{Hubungan Lingkar Pinggang (LP) dengan Gula Darah Puasa}

Pada penelitian ini didapatkan hubungan yang bermakna secara statistik antara lingkar pinggang (LP) dengan gula darah puasa $(p=0,009)$. Hasil ini sesuai dengan Ming Wei, Qiao, Mirzaei yang mendapatkan bahwa hasil pengukuran LP berhubungan lebih baik dibandingkan dengan IMT sebagai prediktor diabetes melitus.(Mirzaei \& Khajeh, 2018; Qiao \& Nyamdorj, 2010; Wei, Gaskill, Haffner, \& Stern, 1997).

Dibandingkan lemak subkutan dan lemak total, lemak viseral berhubungan dengan dislipidemia, inflamasi, resistensi insulin, penyakit jantung koroner dan Non-insulin dependent diabetes melitus (NIDDM). Individu dengan ukuran LP yang lebih tinggi, sekalipun IMT berada dalam rentang normal, lebih berisiko terhadap resistensi insulin dan NIDDM. Dibandingkan dengan ras 
Kaukasia, ras Asia lebih cenderung memiliki fenotip lemak viseral yang berlebih, HDL yang rendah, dan trigliserida yang tinggi.(Wimalawansa \& Johnson, 2013)

Hubungan Rasio Lingkar Pingang terhadap Tinggi Badan (RLPtTB) dengan Gula Darah Puasa Pada penelitian ini tidak didapatkan hubungan yang bermakna secara statistik antara Rasio lingkar pinggang terhadap tinggi badan (RLPtTB) dengan gula darah puasa $(p=0,274)$. Hasil ini sesuai dengan hasil yang didapatkan oleh Al-Zurfi, Mansour. Hal ini berbeda dengan sebagian besar penelitian yang menyatakan bahwa RLPtTB merupakan pengukuran yang lebih baik dibandingkan dengan IMT dan LP untuk memperkirakan resiko metabolik.(Balsam, Aniza, Mohd Rusli, \& Norhayati, 2012; Kodama et al., 2012; Mansour \& Al-Jazairi, 2007; Zhao et al., 2012) Kemungkinan tidak ditemukannya hubungan yang bermakna pada penelitian ini adalah nilai cutoff yang digunakan. Nilai cutoff RLPtTB pada penelitian ini menggunakan nilai 0,5 dimana nilai tersebut sudah baku untuk seluruh populasi sehingga tidak dapat dipengaruhi oleh perbedaan etnis.

Kuo et al dalam penelitiannya menyatakan bahwa pada populasi dengan subjek yang berusia lanjut ditemukan peningkatan nilai ukur lingkar pinggang dan penurunan tinggi badan. Hal ini juga berperan terhadap tingginya nilai RLPtTB. Pada penelitian ini, sebagian besar subjek berusia $30-50$ tahun.

\section{Keterbatasan Penelitian}

Penelitian ini merupakan penelitian pada subjek pengendara bus yang melibatkan jumlah subjek yang cukup besar dibandingkan penelitian sebelumnya. Pada penelitian ini juga dilakukan pemeriksaan antropometri untuk menilai status gizi dari subjek. Antropometri merupakan penilaian yang relatif mudah dilakukan dan banyak dihubungkan dengan berbagai faktor-faktor resiko penyakit metabolik.

Pada penelitian ini belum dilakukan analisis terhadap faktor-faktor resiko metabolik yang lain, sehingga belum dapat dinilai bagaimana pengaruh dari status gizi terhadap kejadian penyakit metabolik lainnya.

\section{KESIMPULAN DAN SARAN}

Pada penelitian ini didapatkan hubungan yang bermakna secara statistik antara indeks massa tubuh, dan lingkar pinggag dengan kadar gula darah puasa $(p<0,05)$, namun tidak didapatkan hubungan bermakna secara statistik antara rasio lingkar pinggang terhadap tinggi badan dengan kadar gula darah puasa $(p>0,05)$ pada pengemudi bus antar kota.

Perlu dilakukan analisis pemeriksaan antropometri terhadap faktor-faktor metabolik lain selain kadar gula darah. Dibutuhkan nilai cutoff yang berbeda untuk pengukuran rasio lingkar pinggang terhadap tinggi badan.

Peningkatan kesadaran terhadap faktor-faktor risiko diabetes melitus pada pengemudi bus seperti mengonsumsi minuman yang manis, kurangnya jam tidur, peningkatan berat badan, lingkar pinggang perlu ditingkatkan melalui edukasi dalam bentuk penyuluhan. Pengemudi bus juga sangat disarankan untuk melakukan pemeriksaan rutin terhadap kadar gula darah. 


\section{DAFTAR PUSTAKA}

Agardh, E. E., Sidorchuk, A., Hallqvist, J., Ljung, R., Peterson, S., Moradi, T., \& Allebeck, P. (2011). Burden of type 2 diabetes attributed to lower educational levels in Sweden. Population Health Metrics, 9(1), 60. https://doi.org/10.1186/1478-7954-9-60

Agrawal, N., Kumar Agrawal, M., Kumari, T., \& Kumar, S. (2017). Correlation between Body Mass Index and Blood Glucose Levels in Jharkhand Population. International Journal of Contemporary Medical Research ISSN (Online, 83(8), 2393-2915. Retrieved from www.ijcmr.com

Akter, S., Goto, A., \& Mizoue, T. (2017). Smoking and the risk of type 2 diabetes in Japan: A systematic review and meta-analysis. Journal of Epidemiology, 27(12), 553-561. https://doi.org/10.1016/j.je.2016.12.017

Ashwell, M. (2011). Charts Based on Body Mass Index and Waist-to-Height Ratio to Assess the Health Risks of Obesity: A Review. The Open Obesity Journal, 3(1), 78-84. https://doi.org/10.2174/1876823701103010078

Attvall, S., Fowelin, J., Lager, I., Von Schenck, H., \& Smith, U. (1993). Smoking induces insulin resistance--a potential link with the insulin resistance syndrome. Journal of Internal Medicine, 233(4), 327-332. Retrieved from http://www.ncbi.nlm.nih.gov/pubmed/8463765

Balsam, M. N.-Z., Aniza, A. A., Mohd Rusli, A., \& Norhayati, M. N. (2012). Waist Height Ratio Compared to Body Mass Index and Waist Circumference in Relation to Glycemic Control in Malay Type 2 Diabetes Mellitus Patients, Hospital Universiti Sains Malaysia. International Journal of Collaborative Research on Internal Medicine \& Public Health, 4(4), 406-415. Retrieved from http://www.iomcworld.com/ijcrimph/files/v04-n04-17.pdf

Bambrick, H. J. (2005). Relationships between BMI, waist circumference, hypertension and fasting glucose: Rethinking risk factors in indigenous diabetes. Australian Indigenous Health Bulletin, 5(4), 1-16.

Bays, H. E., Chapman, R. H., \& Grandy, S. (2007). The relationship of body mass index to diabetes mellitus, hypertension and dyslipidaemia: Comparison of data from two national surveys. International Journal of Clinical Practice, 61(5), 737-747. https://doi.org/10.1111/j.1742-1241.2007.01336.x

Browning, L. M., Hsieh, S. D., \& Ashwell, M. (2010). A systematic review of waist-to-height ratio as a screening tool for the prediction of cardiovascular disease and diabetes: 05 could be a suitable global boundary value. Nutrition Research Reviews, 23(2), 247-269. https://doi.org/10.1017/S0954422410000144

Buchholz, A. C., \& Bugaresti, J. M. (2005). A review of body mass index and waist circumference as markers of obesity and coronary heart disease risk in persons with chronic spinal cord injury. Spinal Cord, 43(9), 513-518. https://doi.org/10.1038/sj.sc.3101744

Carrero, J. J., \& Avesani, C. M. (2015). Pros and Cons of Body Mass Index as a Nutritional and Risk Assessment Tool in Dialysis Patients. Seminars in Dialysis, 28(1), 48-58. https://doi.org/10.1111/sdi.12287

Chen, L., Pei, J. H., Kuang, J., Chen, H. M., Chen, Z., Li, Z. W., \& Yang, H. Z. (2015). Effect of lifestyle intervention in patients with type 2 diabetes: A meta-analysis. Metabolism: Clinical and Experimental, 64(2), 338-347. https://doi.org/10.1016/j.metabol.2014.10.018

Colberg, S. R., Sigal, R. J., Yardley, J. E., Riddell, M. C., Dunstan, D. W., Dempsey, P. C., ... Tate, D. F. (2016). Physical activity/exercise and diabetes: A position statement of the American Diabetes Association. Diabetes Care, 39(11), 2065-2079. https://doi.org/10.2337/dc16-1728

Dam, R. M. Van, Willett, W. C., Manson, J. E., \& Hu, F. B. (2006). Coffee, Caffeine, and Risk of Type 2 Diabetes. Diabetes Care, 29(2), 398-403. https://doi.org/10.1093/occmed/kqh123 
Eliasson, B., Mero, N., Taskinen, M. R., \& Smith, U. (1997). The insulin resistance syndrome and postprandial lipid intolerance in smokers. Atherosclerosis, 129(1), 79-88. Retrieved from http://www.ncbi.nlm.nih.gov/pubmed/9069521

Facchini, F. S., Hollenbeck, C. B., Jeppesen, J., Chen, Y. D., \& Reaven, G. M. (1992). Insulin resistance and cigarette smoking. Lancet (London, England), 339(8802), 1128-1130. Retrieved from http://www.ncbi.nlm.nih.gov/pubmed/1349365

Garber, C. E., Blissmer, B., Deschenes, M. R., Franklin, B. A., Lamonte, M. J., Lee, I. M., ... Swain, D. P. (2011). Quantity and quality of exercise for developing and maintaining cardiorespiratory, musculoskeletal, and neuromotor fitness in apparently healthy adults: Guidance for prescribing exercise. Medicine and Science in Sports and Exercise, 43(7), 1334-1359. https://doi.org/10.1249/MSS.0b013e318213fefb

Heckman, M. A., Weil, J., \& de Mejia, E. G. (2010). Caffeine (1, 3, 7-trimethylxanthine) in Foods: A Comprehensive Review on Consumption, Functionality, Safety, and Regulatory Matters. Journal of Food Science, 75(3), R77-R87. https://doi.org/10.1111/j.17503841.2010.01561.x

Hirata, R. P., Sampaio, L. M. M., Leitão Filho, F. S. S., Braghiroli, A., Balbi, B., Romano, S., ... Oliveira, L. V. F. de. (2012). General Characteristics and Risk Factors of Cardiovascular Disease among Interstate Bus Drivers. The Scientific World Journal, 2012, 1-7. https://doi.org/10.1100/2012/216702

Izadi, N., Malek, M., Aminian, O., \& Saraei, M. (2013). Medical risk factors of diabetes mellitus among professional drivers. 12, 1. https://doi.org/10.1186/2251-6581-12-23

Kim, C. H. (2016). Measurements of adiposity and body composition. The Korean Journal of Obesity, 25(3), 115-120. https://doi.org/10.1093/acprof

Kim, D., Kim, J., \& Jeong, H. (2017). Comparison of body mass index, waist circumference, and waist-to-height ratio as a predictors of abdominal fat distribution in male examinees from the health promotion center. 7(4), 596-599.

Koch, E., Romero, T., Romero, C. X., Aguilera, H., Paredes, M., Vargas, M., \& Ahumada, C. (2010). Early Life and Adult Socioeconomic Influences on Mortality Risk: Preliminary Report of a 'Pauper Rich' Paradox in a Chilean Adult Cohort. Annals of Epidemiology, 20(6), 487-492. https://doi.org/10.1016/j.annepidem.2010.03.009

Kodama, S., Horikawa, C., Fujihara, K., Heianza, Y., Hirasawa, R., Yachi, Y., ... Sone, H. (2012). Comparisons of the strength of associations with future type 2 diabetes risk among anthropometric obesity indicators, including waist-to-height ratio: A meta-analysis. American Journal of Epidemiology, 176(11), 959-969. https://doi.org/10.1093/aje/kws172

Lakshman, A., Manikath, N., Rahim, A., \& Anilakumari, V. P. (2014). Prevalence and Risk Factors of Hypertension among Male Occupational Bus Drivers in North Kerala, South India: A Cross-Sectional Study. ISRN Preventive Medicine, 2014, 1-9. https://doi.org/10.1155/2014/318532

Lam, B. C. C., Koh, G. C. H., Chen, C., Wong, M. T. K., \& Fallows, S. J. (2015). Comparison of Body Mass Index (BMI), Body Adiposity Index (BAI), Waist Circumference (WC), WaistTo-Hip Ratio (WHR) and Waist-To-Height Ratio (WHtR) as predictors of cardiovascular disease risk factors in an adult population in Singapore. PLoS ONE, 10(4), 1-15. https://doi.org/10.1371/journal.pone.0122985

Lin, X., Zhang, X., Guo, J., Roberts, C. K., McKenzie, S., Wu, W. C., ... Song, Y. (2015). Effects of exercise training on cardiorespiratory fitness and biomarkers of cardiometabolic health: A systematic review and meta-analysis of randomized controlled trials. Journal of the American Heart Association, 4(7), 1-28. https://doi.org/10.1161/JAHA.115.002014

Mansour, A. A., \& Al-Jazairi, M. I. (2007). Predictors of incident diabetes mellitus in Basrah, Iraq. Annals of Nutrition and Metabolism, 51(3), 277-280. 
https://doi.org/10.1159/000105449

Mansur, A. de P., Rocha, M. A., Leyton, V., Takada, J. Y., Avakian, S. D., Santos, A. J., ... Rohlfs, W. J. C. (2015). Risk Factors for Cardiovascular Disease, Metabolic Syndrome and Sleepiness in Truck Drivers. Arquivos Brasileiros de Cardiologia, 560-565. https://doi.org/10.5935/abc.20150132

Mirzaei, M., \& Khajeh, M. (2018). Comparison of anthropometric indices (body mass index, waist circumference, waist to hip ratio and waist to height ratio) in predicting risk of type II diabetes in the population of Yazd, Iran. Diabetes \& Metabolic Syndrome: Clinical Research \& Reviews, 12(5), 677-682. https://doi.org/10.1016/j.dsx.2018.04.026

Mohebbi, I., Matinkhah, M., Nabizadeh, F., Blouri, A., Saba, A. L. I., \& Shirazi, A. (2010). The Metabolic Syndrome and its Association with Over Time Driving in Iranian Professional Bus Drivers. 2(1), 37-41.

Moreno, C. R. C., Louzada, F. M., Teixeira, L. R., Borges, F., \& Lorenzi-Filho, G. (2006). Short sleep is associated with obesity among truck drivers. Chronobiology International, 23(6), 1295-1303. https://doi.org/10.1080/07420520601089521

Morriison, S., Colberg, M., Mariano, M., Parson, H. K., \& Vinik, A. I. (2010). Balance training reduces falls risk in older individuals with type 2 diabetes. Diabetes Care, 33(4), 748-750. https://doi.org/10.2337/dc09-1699

Müller, M. J., Braun, W., Enderle, J., \& Bosy-Westphal, A. (2016). Beyond BMI: Conceptual Issues Related to Overweight and Obese Patients. Obesity Facts, 9(3), 193-205. https://doi.org/10.1159/000445380

Picone, G., Gray, N., Sloan, F., \& Yashkin, A. (2015). The relationship between BMI and onset of diabetes mellitus and its complications. South Med J, 108(1), 29-36. https://doi.org/10.14423/SMJ.0000000000000214.The

Qiao, Q., \& Nyamdorj, R. (2010). Is the association of type II diabetes with waist circumference or waist-to-hip ratio stronger than that with body mass index. European Journal of Clinical Nutrition, 64(1), 30-34. https://doi.org/10.1038/ejen.2009.93

Rimm, E. B., Chan, J., Stampfer, M. J., Colditz, G. A., \& Willett, W. C. (1995). Prospective study of cigarette smoking, alcohol use, and the risk of diabetes in men. BMJ (Clinical Research Ed.), 310(6979), 555-559. Retrieved from http://www.ncbi.nlm.nih.gov/pubmed/7888928

Saberi, H. R., Moravveji, A. R., Fakharian, E., Kashani, M. M., \& Dehdashti, A. R. (2011). Prevalence of metabolic syndrome in bus and truck drivers in Kashan, Iran. Diabetology and Metabolic Syndrome, 3(1), 8. https://doi.org/10.1186/1758-5996-3-8

Sacerdote, C., Ricceri, F., Rolandsson, O., Baldi, I., Chirlaque, M.-D., Feskens, E., ... Wareham, N. (2012). Lower educational level is a predictor of incident type 2 diabetes in European countries: The EPIC-InterAct study. International Journal of Epidemiology, 41(4), 11621173. https://doi.org/10.1093/ije/dys091

Siddiqui, A. A., Siddiqui, S. A., Ahmad, S., Siddiqui, S., Ahsan, I., \& Sahu, K. (2013). Diabetes: Mechanism, Pathophysiology and Management-A Review. International Journal of Drug Development \& Research, 5(2), 1-23. Retrieved from http://www.ijddr.in/drugdevelopment/diabetes-mechanism-pathophysiology-and-managementa-review.pdf

Siu, S. C., Wong, K. W., Lee, K. F., Lo, Y. Y. C., Wong, C. K. H., Chan, A. K. L., ... Lam, C. L. K. (2012). Prevalence of undiagnosed diabetes mellitus and cardiovascular risk factors in Hong Kong professional drivers. Diabetes Research and Clinical Practice, 96(1), 60-67. https://doi.org/10.1016/j.diabres.2011.12.002

Sluik, D., Buijsse, B., Muckelbauer, R., Kaaks, R., Teucher, B., Johnsen, N. F., ... Nöthlings, U. (2012). Physical activity and mortality in individuals with diabetes mellitus: A prospective 
study and meta-analysis. Archives of Internal Medicine, 172(17), 1285-1295. https://doi.org/10.1001/archinternmed.2012.3130

Smolensky, M. H., Di Milia, L., Ohayon, M. M., \& Philip, P. (2011). Sleep disorders, medical conditions, and road accident risk. Accident Analysis and Prevention, 43(2), 533-548. https://doi.org/10.1016/j.aap.2009.12.004

Snowling, N. J., \& Hopkins, W. G. (2006). Effects of different modes of exercise training on glucose control and risk factors for complications in type 2 diabetic patients: A metaanalysis. Diabetes Care, 29(11), 2518-2527. https://doi.org/10.2337/dc06-1317

Suastika, K., Dwipayana, P., Semadi, M. S., \& Kuswardhani, R. T. (2018). Age is an Important Risk factor for Type 2 Diabetes Mellitus and Cardiovascular Diseases. In Glucose Tolerance (Vol. 2, pp. 67-80). https://doi.org/10.5772/32009

Vazquez, G., Duval, S., Jacobs, D. R., \& Silventoinen, K. (n.d.). Comparison of Body Mass Index, Waist Circumference, and Waist/Hip Ratio in Predicting Incident Diabetes: A MetaAnalysis. https://doi.org/10.1093/epirev/mxm008

Wei, M., Gaskill, S., Haffner, S., \& Stern, M. (1997). Waist Circumference as the Best Predictor of Noninsulin Dependent Diabetes Mellitus (NIDDM) Compared to Body Mass Index, Waist/hip Ratio and Other. Obesity Research, 5(1). Retrieved from http://onlinelibrary.wiley.com/doi/10.1002/j.1550-8528.1997.tb00278.x/abstract

Will, J. C., Galuska, D. A., Ford, E. S., Mokdad, A., \& Calle, E. E. (2001). Cigarette smoking and diabetes mellitus: evidence of a positive association from a large prospective cohort study. International Journal of Epidemiology, 30(3), 540-546. Retrieved from http://www.ncbi.nlm.nih.gov/pubmed/11416080

Wimalawansa, S. J., \& Johnson, R. W. (2013). Visceral adiposity and cardiometabolic risks: epidemic of abdominal obesity in North America. Research and Reports in Endocrine Disorders, 3(February), 17-30. https://doi.org/10.2147/RRED.S32041

World Health Organization. (2016). Global Report on Diabetes. In World Health Organization. Retrieved from http://www.who.int/about/licensing/

Zhao, X., Zhu, X., Zhang, H., Zhao, W., Li, J., Shu, Y., ... Li, Y. (2012). Prevalence of diabetes and predictions of its risks using anthropometric measures in southwest rural areas of China. BMC Public Health, 12, 1. https://doi.org/10.1186/1471-2458-12-821 